\title{
Pengembangan Modul Berbasis Aplikasi Android untuk Mata Kuliah Ilmu Bahan Teknik pada Prodi D3 Teknik Mesin Universitas Negeri Malang
}

\author{
Ahmat Robianto $^{1}$, Wahono ${ }^{2}$, Marsono $^{3}$ \\ ${ }^{1,2,3}$ Program Studi S1 Pendidikan Teknik Mesin Jurusan Teknik Mesin \\ ${ }^{1,2,3}$ Fakultas Teknik Universitas Negeri Malang \\ 1,2,3 Jalan Semarang No. 5, Malang 65145 \\ Email: ahmatrobianto@gmail.com
}

\begin{abstract}
Abstrak: Mata kuliah Ilmu Bahan Teknik merupakan mata kuliah wajib bagi mahasiswa Jurusan Teknik Mesin Fakultas Teknik Universitas Negeri Malang. Pembelajaran dengan sistem konvensional dalam proses pembelajaran Ilmu Bahan Teknik saat ini sudah bagus, namun dalam segi pemanfaatan dan penggunaan media pembelajaran masih kurang efektif, dan bisa dikembangkan lagi agar pembelajaran bisa lebih bervariasi dan mampu menjadikan mahasiswa dapat belajar secara mandiri. Tujuan penelitian dan pengembangan ini antara lain mengembangkan produk berupa modul berbasis aplikasi android untuk mata kuliah Ilmu Bahan Teknik serta mengetahui tingkat daya tarik mahasiswa terkait modul berbasis aplikasi android yang digunakan. Hasil validasi yang diperoleh adalah sebagai berikut: (1) validasi konstruk menunjukkan persentase $75 \%$, (2) validasi konten menunjukkan persentase $79,41 \%$ (3) hasil face validity oleh kelompok kecil menunjukkan persentase 70,59\%, (4) validasi ahli media menunjukkan persentase 90,63\%, dan (5) ujicoba daya tarik oleh kelompok besar menunjukkan persentase $81,11 \%$.
\end{abstract}

Kata Kunci: pengembangan modul, android, ilmu bahan teknik.

Abstract: Engineering Materials Courses are compulsory subjects for students of the Mechanical Engineering Department, Faculty of Engineering, State University of Malang. Learning with conventional systems in the learning process of Engineering Materials is currently good, but in terms of the use and use of instructional media is still less effective, and can be further developed so that learning can be more varied and able to make students able to learn independently. The purpose of this research and development includes developing a product in the form of an android application-based module for the subject of Engineering Materials and knowing the level of attractiveness of students related to the android application-based module used. The validation results obtained are as follows: (1) construct validation shows a percentage of $75 \%$, (2) content validation shows a percentage of $79.41 \%$ (3) results of face validity by small groups show a percentage of $70.59 \%$, (4) expert validation the media showed a percentage of $90.63 \%$, and (5) a trial of attractiveness by a large group showed a percentage of $81.11 \%$.

Keywords: module development, android, material engineering.

Pembelajaran merupakan suatu proses kegiatan belajar mengajar yang juga berperan dalam menentukan keberhasilan belajar peserta didik. Menurut Sagala (2006:61) bahwa pembelajaran adalah membelajarkan peserta didik dengan menggunakan asas pendidikan maupun teori belajar merupakan penentu utama keberhasilan pendidikan. Dalam Peraturan Menteri Pendidikan Nasional Nomor 41 Tahun 2007 mengenai Standar Proses untuk Satuan Pendidikan Dasar dan Menengah, diuraikan bahwa, pembelajaran adalah proses interaksi pendidik dan peserta didik serta sumber belajar dalam proses kegiatan belajar mengajar pada suatu lingkungan belajar. Adapun komponen yang mempengaruhi berjalannya suatu proses pembelajaran untuk mewujudkan tujuan di atas yaitu: 1) guru, 2) siswa, 3) materi pembelajaran, 4) metode pembelajaran, 5) media pembelajaran, 6) evaluasi pembelajaran (Zain \& Djamarah, 2006:48). Kemampuan peserta didik dalam menangkap materi yang diberikan oleh pendidik adalah salah satu indikator keberhasilan proses pembelajaran. Supaya keberhasilan proses pembelajaran tercapai maka perlu meningkatkan kualitas dari pembelajaran tersebut. Pembelajaran dapat meningkat apabila dilakukan pengelolaan pada media pembelajarannya. Media pembelajaran yang interaktif sangat dibutuhkan dalam kegiatan belajar mengajar agar peserta didik mampu belajar secara mandiri, dan pembelajaran menjadi efektif.

Media pembelajaran memiliki peranan yang penting dalam menyampaikan suatu informasi yang diberikan pendidik kepada peserta didik. Sejalan dengan pendapat Asmani (2011:48) yang menyatakan bahwa media pembelajaran merupakan wadah atau medium perantara dari pesan yang hendak diteruskan atau disampaikan oleh pendidik kepada peserta didik. Dalam dunia pembelajaran, pesan yang ingin disampaikan tersebut adalah pesan pembelajaran atau materi yang disampaikan. Media pembelajaran harus dibuat semenarik mungkin agar peserta didik bisa mempelajari suatu materi dengan mudah. Salah satu media pembelajaran yang masih dipakai sekarang adalah menggunakan media pembelajaran berupa buku. Kurang variatifnya media yang digunakan bukan semata-mata kesalahan pendidik, namun karena kurang mengoptimalkan perkembangan teknologi. 
Perkembangan teknologi dan informasi (TIK) saat ini begitu pesat, salah satu perangkat TIK yang saat ini sudah umum digunakan adalah smartphone. Pertumbuhan pengguna smartphone di Indonesia lumayan tinggi. Untuk pemakai muda (18-34 tahun) kepemilikan smartphone meningkat dari 39 persen menjadi 66 persen dari 2015-2018 (tempo.co, Maret 2019). Pemakai muda (18-34 tahun) dapat dikatakan sebagian adalah mahasiswa milenial pasti sudah memiliki atau mempunyai satu smartphone atau bahkan ada yang mempunyai lebih dari satu smartphone. Semakin banyaknya mahasiswa yang memiliki dan menggunakan smartphone, maka semakin besar pula peluang penggunaan perangkat teknologi dalam dunia pendidikan. Media pembelajaran yang memanfaatkan teknologi smartphone disebut dengan mobile learning (M-Learning).

Mobile learning merupakan salah satu alternatif dalam mengembangkan media pembelajaran agar menjadi lebih menarik. Kehadiran mobile learning ditujukan sebagai pelengkap pembelajaran serta memberikan kesempatan pada peserta didik untuk mempelajari materi yang kurang dikuasai di mana saja dan kapan saja (Wirawan, 2011:22). Mobile learning merupakan perkembangan pembelajaran yang berbasis pada teknologi informasi dan komunikasi yang portable sehingga mudah dibawa kemanapun, misalnya handphone, Ipad, dan sejenisnya (Subkhan, 2016:12). Penggunaan mobile learning dapat menunjang proses belajar mengajar dan bisa menambah fleksibilitas dalam kegiatan belajar mengajar sehingga hasil belajar lebih baik.

Penggunaan mobile learning dengan menggunakan android sebagai media pembelajaran merupakan hal yang baru dalam dunia pendidikan, selama ini android digunakan untuk kebutuhan berbagi informasi dan komunikasi. Penggunaan android baik dalam smartphone maupun computer diharapkan dapat digunakan untuk membuat media pembelajaran yang sangat menarik sehingga proses untuk mencapai tujuan pembelajaran akan berjalan dengan lancar. Jurusan Teknik Mesin terdapat beberapa matakuliah yang nantinya akan berguna ketika mahasiswa memasuki dunia industri manufaktur, salah satunya adalah matakuliah Ilmu Bahan Teknik. Ilmu bahan teknik adalah ilmu yang mempelajari tentang sifat bahan dan aplikasinya dibidang ilmu dan teknik. Matakuliah Ilmu Bahan Teknik merupakan matakuliah yang diajarkan pada mahasiswa Jurusan Teknik Mesin Fakultas Teknik Universitas Negeri Malang. Matakuliah ini memiliki bobot dua satuan kredit semester (SKS) dan empat jam studi (JS). Matakuliah ini merupakan matakuliah wajib bagi mahasiswa Jurusan Teknik Mesin Fakultas Teknik Universitas Negeri Malang yang ditempuh selama enam belas kali pertemuan dengan empat jam studi setiap pertemuannya.

Berdasarkan hasil analisis kebutuhan yang dilakukan kepada 20 mahasiswa Program Studi S1 Pendidikan Teknik Mesin 2017 Universitas Negeri Malang yang sudah menempuh mata kuliah Ilmu Bahan Teknik. Mahasiswa dalam satu kelas sudah memiliki smartphone android, tetapi ada yang belum menggunakan secara maksimal dalam pendidikan. Pembelajaran dengan sistem konvensional yang diterapkan dalam proses pembelajaran Ilmu Bahan Teknik saat ini sudah bagus, namun dalam segi pemanfaatan dan penggunaan media pembelajaran masih kurang efektif, dan bisa dikembangkan lagi agar pembelajaran bisa lebih bervariasi dan mampu menjadikan mahasiswa dapat belajar secara mandiri. Mahasiswa mendapatkan sumber belajar dari projector screen, penjelasan dosen dan catatan pribadi mahasiswa sendiri. Akibatnya mahasiswa belum dapat melakukan kegiatan belajar secara mandiri, memaksimalkan pemahaman dan megembangkan materi yang diterima.

Suasana pada saat perkuliahan terjadi, mahasiswa menjadi pasif dan memiliki minat baca yang rendah, sehingga perlu solusi untuk mengatasi permasalahan tersebut. Pengembangan modul merupakan salah satu solusi untuk membantu mahasiswa dan dosen dalam kegiatan belajar yang memiliki tujuan untuk meningkatkan kemampuan mahasiswa dalam memahami materi, meningkatkan keaktifan di dalam kelas dan meningkatkan minat baca. Dengan adanya modul, mahasiswa diharapkan dapat melakukan kegiatan belajar secara mandiri dengan atau tanpa kehadiran dosen pengajar. Pembelajaran akan semakin mudah dan lancar tanpa memakan waktu dosen untuk menjelaskan materi.

\section{METODE}

Model pengembangan yang digunakan dalam penelitian dan pengembangan ini adalah model Research and Development (R \& D). Menurut Sukmadinata (2007) Penelitian dan Pengembangan atau Research and Development (R \& D) adalah suatu proses atau langkah-langkah untuk mengembangkan suatu produk baru, atau menyempurnakan prosuk yang telah ada yang dapat dipertanggungjawabkan, langkah-langkah penelitian dan pengembangan yang digunakan adalah berdasarkan model ADDIE, yaitu Analysis (Analisis), Design (Desain), Development (Pengembangan), Implementation (Implementasi), dan Evaluation (Evaluasi). Alur penelitian ADDIE dapat dilihat pada gambar 1. 


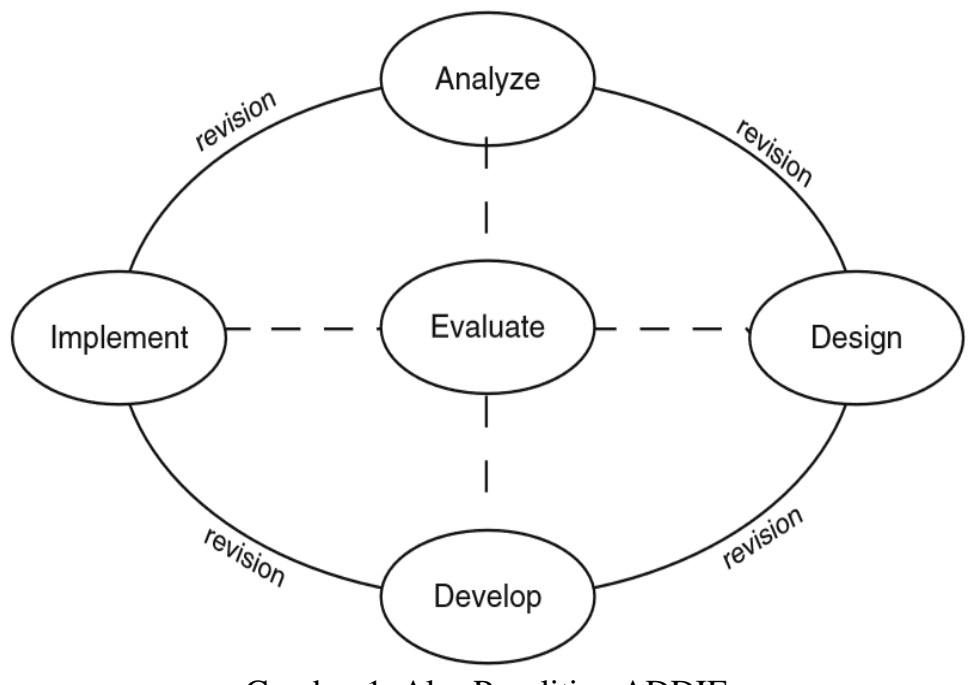

Gambar 1. Alur Penelitian ADDIE

Sumber: Mulyatiningsih (2011)

Tahap pertama yang ada dalam pengembangan model ADDIE adalah tahap Analisis. Tahap analisis terdiri dari analisis mata kuliah, analisis karakteristik mahasiswa, dan analisis media pendukung. Selanjutnya yang kedua adalah tahap Desain, Tahap ini dikenal dengan istilah membuat rancangan, tahap desain terdiri dari desain capaian pembelajaran dan strategi pengembangan media. Setelah melalui tahap kedua kemudian lanjut pada tahap yang ketiga, tahap ketiga ini adalah tahap Pengembangan. Pengembangan merupakan proses mewujudkan desain yang sudah dirancang menjadi real. Dalam artian pada tahap ini segala sesuatu yang dibutuhkan atau segala sesuatu pendukung proses penyusunan produk harus disiapkan secara keseluruhan. Tahap pengembangan terdiri dari proses pengembangan dan hasil pengembangan. Kemudian lanjut ke tahap 4, tahap 4 ini adalah tahap Implementasi. Implementasi atau penerapan merupakan tahap untuk menerapkan sistem ataupun program yang dikembangkan. Pada tahap ini diujicobakan oleh ahli materi, kelompok kecil, ahli media, dan kelompok besar. Tahap yang terakhir adalah tahap evaluasi. Evaluasi merupakan proses untuk menentukan apakah produk yang sudah tercipta memenuhi persyaratan kelayakan untuk dioperasikan. Pada tahap evaluasi terdiri dari pengumpulan data, perbaikan media, dan produk jadi.

Desain uji coba secara keseluruhan dilakukan dalam 4 tahap, yaitu ahli materi untuk mengetahui validasi konstruk dan konten, kemudian diujicobakan oleh kelompok kecil sebanyak 10 mahasiswa untuk mengetahui tingkat face validity. Menurut Suparman (1997) jumlah yang diperlukan untuk uji coba kelompok kecil hanya 8-20 responden, selanjutnya ke ahli media untuk mengetahui tingkat kelayakan media, dan diujicobakan ke kelompok besar sebanyak 30 mahasiswa untuk mengetahui tingkat daya tarik. Jumlah responden yang digunakan dalam uji coba ini lebih besar daripada uji coba kelompok kecil. Menurut Suparman (1997) jumlah responden yang digunakan dalam uji coba lapangan adalah 15-30 responden.

Subjek penelitian dalam penelitian dan pengembangan ini adalah Dosen Teknik Mesin dan mahasiswa D3 Teknik Mesin Universitas Negeri Malang. Objek penelitian pada penelitian dan pengembangan ini adalah modul berbasis aplikasi untuk mata kuliah Ilmu Bahan Teknik.

Jenis data uji coba produk yang digunakan dalam penelitian dan pengembangan modul berbasis aplikasi android untuk mata kuliah Ilmu Bahan Teknik yaitu data kuantitatif. Data kuantitatif diperoleh dari penyebaran angket kepada penguji uji validasi ahli, responden uji coba kelompok kecil, dan responden uji coba lapangan. Data tersebut kemudian akan diolah dan dijadikan dasar penilaian kelayakan produk aplikasi yang dikembangkan.

Instrumen pengumpulan data yang digunakan dalam penelitian dan pengembangan modul berbasis aplikasi android untuk mata kuliah Ilmu Bahan Teknik ini menggunakan angket. Tujuan penggunaan angket ini adalah untuk memperoleh data kuantitatif demi kesempurnaan dan kelayakan program aplikasi yang dihasilkan. Pengumpulan data dilakukan pada tahap uji coba produk. Jenis angket yang digunakan dalam penelitian ini yaitu angket semi tertutup dengan menggunakan skala likert.

Metode analisa data penelitian menggunakan metode deskriptif. Analisis deskriptif adalah analisis yang digunakan untuk menguji variabel yang bersifat kuantitatif. Metode deskriptif adalah suatu metode dalam meneliti status sekelompok manusia, suatu objek, suatu konteks, suatu sistem pemikiran, ataupun suatu kelas peristiwa pada masa sekarang. Tujuan dari penelitian deskriptif ini adalah untuk membuat deskripsi, menggambarkan atau melukiskan secara sitematis, faktual, dan akurat mengenai fakta-fakta, sifat-sifat serta hubungan antar fenomena yang diselidiki. Mulyatiningsih (2011) berpendapat bahwa analisis deskriptif data secara deskriptif dipakai untuk mendiskripsikan data yang telah dikumpulkan apa adanya dan tidak digunakan untuk mengambil kesimpulan statistik. Teknik pengolahan data menggunakan pengukuran dengan skala likert. Menurut Sugiyono (2011), menjelaskan bahwa skala likert digunakan untuk mengukur sikap, pendapat, dan persepsi seseorang atau kelompok orang tentang sebuah fenomena sosial. Skala likert dapat memberikan alternatif jawaban dari sosial instrumen 
dengan gradasi dari sangat positif hingga sangat negatif. Pertimbangan pemilihan pengukuran ini karena memudahkan responden untuk memilih jawaban. Kriteria jawaban yang dibagikan kepada responden menggunakan kuisinoer/angket berupa pengukuran skala likert, responden diminta menggunakan program aplikasi secara keseluruhan dengan berhadapan secara langsung. Responden diminta memberikan salah satu pilihan dari jawaban yang telah disediakan.

\section{HASIL DAN PEMBAHASAN}

Hasil pengembangan adalah pembahasan hasil dari penelitian yang sudah dilaksanakan oleh pengembang berdasarkan data dan fakta yang sudah diperoleh. Pada bab ini berisi tentang hasil analisis kebutuhan, hasil desain, hasil pengembangan, hasil validasi ahli, hasil implementasi dan hasil evaluasi.

\section{Hasil Analisis Kebutuhan}

Analisis kebutuhan dilaksanakan dengan tujuan untuk mengetahui apakah diperlukan pengembangan modul pada mata kuliah Ilmu Bahan Teknik untuk menunjang proses pembelajaran. Terdapat tiga hasil analisis yang ada dalam pengembangan modul Ilmu Bahan Teknik ini, hasil tersebut berupa hasil analisis mata kuliah Ilmu Bahan Teknik, hasil analisis karakteristik mahasiswa, dan hasil analisis media pendukung (software dan hardware). Hasil dari analisis mata kuliah Ilmu Bahan Teknik didapatkan Berdasarkan kurikulum 2018 Program Studi D3 Teknik Mesin yang terdapat di Jurusan Teknik Mesin Universitas Negeri Malang yang meliputi, 1) Mengenal berbagai jenis material yang lazim digunakan dibidang manufaktur. 2) Mengklasifikasikan material berdasarkan jenis dan penggunaan. 3) Mendeskripsikan ilmu logam ekstraks (pengolahan bijih besi, melebur besi tuang, dan mengolah baja). 4) Mendeskripsikan ilmu logam fisik (sifat, cara pengerjaan dan pengaruhnya). 5) Menjelaskan jenis, sifat, dan penggunaan material logam (ferro dan non ferro). 6) Menjelaskan jenis, sifat, dan penggunaan material polimer (thermo plastik dan duro plastik). 7) Menjelaskan jenis, sifat, dan penggunaan material komposit.

Tahap analisis karakteristik merupakan tahapan awal untuk mengetahui apakah diperlukan pengembangan media pembelajaran untuk mata kuliah Ilmu Bahan Teknik. Analisis kebutuhan dilakukan kepada 20 Mahasiswa Program Studi S1 Pendidikan Teknik Mesin 2017. Hasil analisis kebutuhan yang diperoleh peneliti antara lain: 1) Pada poin 1 tentang kepemilikan smartphone android tiap individu. Dapat diketahui dari 20 responden memilih ya dengan persentase $100 \%$. Ini berarti bahwa semua responden memiliki smartphone android. 2) Pada poin 2 tentang pemanfaatan laptop atau smartphone android untuk kepentingan pendidikan secara maksimal. Dapat diketahui 17 dari 20 responden memilih ya dengan persentase 85\% dan 3 dari 20 responden memilih tidak dengan persentase 15\%. Ini berarti bahwa mahasiswa sudah memanfaatkan laptop dan smartphone android untuk kepentingan pendidikan secara maksimal. 3) Pada poin 3 tentang kesulitan dalam memahami materi pembelajaran Ilmu Bahan Teknik. Dapat diketahui 10 dari 20 responden memilih ya dengan persentase 50\% dan 10 dari 20 responden memilih tidak dengan persentase 50\%. Ini berarti bahwa sebagian dari mahasiswa masih mengalami kesulitan dalam memahami pembelajaran Ilmu Bahan Teknik. 4) Pada poin 4 tentang terdapatnya modul atau hand out pada pembelajaran Ilmu Bahan Teknik. Dapat diketahui 2 dari 20 responden memilih ya dengan persentase 10\%, dan 18 dari 20 responden memilih tidak dengan persentase $90 \%$. Ini berarti bahwa dalam pembelajaran mata kuliah Ilmu Bahan Teknik masih belum terdapat modul atau hand out. 5) Pada poin 5 tentang pengaruh pemberian materi Ilmu Bahan Teknik ketika melakukan praktik pengujian logam. Dapat diketahui 17 dari 20 responden memilih ya dengan persentase 85\%, dan 3 dari 20 responden memilih tidak dengan persentase 15\%. Ini berarti bahwa pemberian materi Ilmu Bahan Teknik memberikan pengaruh signifikan saat pengujian logam. 6) Pada poin 6 tentang perasaan responden jika terdapat media pembelajaran pada mata kuliah Ilmu Bahan Teknik. Dapat diketahui dari 20 responden memilih ya dengan persentase 100\%. Ini berarti bahwa semua responden akan senang jika terdapat media pembelajaran berbasis aplikasi android pada mata kuliah Ilmu Bahan Teknik. 7) Pada poin 7 tentang kesesuaian penggunaan aplikasi android sebagai media pembelajaran pada mata kuliah Ilmu Bahan Teknik. Dapat diketahui 19 dari 20 responden memilih ya dengan persentase $95 \%$ dan 1 dari 20 responden memilih tidak dengan persentase 5\%. Ini berarti bahwa sebagian besar responden setuju dengan penggunaan aplikasi android sebagai media pembelajaran Ilmu Bahan Teknik. 8) Pada poin 8 tentang pengalaman menggunakan media pembelajaran serupa dalam kegiatan pembelajaran. Dapat diketahui 5 dari 20 responden memilih ya dengan persentase $25 \%$, dan 15 dari 20 responden memilih tidak dengan persentase $75 \%$. Ini berarti bahwa sebagian besar mahasiswa masih belum pernah menggunakan media pembelajaran serupa dalam kegiatan pembelajaran. 9) Pada poin 9 tentang penggunaan media pembelajaran berbasis aplikasi android akan dapat meningkatkan motivasi belajar. Dapat diketahui dari 18 dari 20 responden memilih ya dengan persentase $90 \%$ dan 2 dari 20 responden memilih tidak dengan persentase 10\%. Ini berarti bahwa media pembelajaran berbasis aplikasi android akan dapat meningkatkan motivasi belajar mahasiswa.

Hasil analisis media pendukung (software dan hardware) berupa perangkat yang digunakan dalam membuat modul berbasis aplikasi android pada mata kuliah Ilmu Bahan Teknik adalah Smart App Creator yang dioperasikan dengan menggunakan laptop, sedangkan hasil dari software tersebut berupa aplikasi yang digunakan pada android dengan sistem operasi minimal Kitkat. 


\section{Hasil Desain}

Berdasarkan prosedur model pengembangan ADDIE yang digunakan oleh pengembang terdapat proses desain yang bertujuan untuk menentukan rancangan awal sebuah produk yang sedang dikembangkan. Dalam pengembangan modul berbasis aplikasi android ini meliputi capaian pembelajaran dan strategi pengembangan. Capaian pembelajaran berisi kompetensi-kompetensi yang ada dalam setiap kegiatan pembelajaran dan hasil dari strategi pengembangan ini berupa storyboard yang nantinya digunakan sebagai panduan dalam proses pembuatan aplikasi modul tersebut.

\section{Hasil Pengembangan}

Setelah melakukan tahapan desain pembuatan media pembelajaran yang telah ditetapkan seperti dalam storyboard maka selanjutnya adalah proses pembuatan aplikasi modul tersebut dan akan dihasilkan modul berbasis aplikasi android dengan judul ILMU BAHAN TEKNIK. Dalam kegiatan pengembangan terdapat proses dalam pengembangan dan hasil dari pengembangan tersebut. Proses pengembangan meliputi persiapan modul dan software Smart Apps Creator, pelaksanaan proses pembuatan modul sesuai dengan desain yang sudah dibuat sebelumnya, dan proses editing produk yaitu proses menambahkan atau memperbarui apa yang diperlukan misalnya materi, tampilan atau komponen lain yang ada dalam aplikasi modul tersebut, sedangkan hasil pengembangan media berupa tampilan menu utama yang terdiri dari beberapa tombol seperti, 1) Panduan, berisi panduan dalam menggunakan modul berbasis aplikasi android oleh mahasiswa, dosen, dan cara menggunakan aplikasi. 2) Kegiatan belajar, berisi tentang bab-bab yang sudah tersedia berdasarkan kompetensi yang ada. 3) Bab-bab terdiri dari beberapa menu yaitu materi, latihan soal, penilaian, kunci jawaban, dan daftar rujukan. 4) Informasi, berisi identitas pengembang serta dosen pembimbing yang sudah membantu dalam proses pengembangan modul berbasis aplikasi android pada mata kuliah Ilmu Bahan Teknik. 5) Keluar aplikasi dengan menggunakan tombol kembali yang sudah tersedia di android masing-masing.

\section{Hasil Validasi Ahli Materi}

Validasi modul cetak oleh ahli materi dilaksanakan pada tanggal 28 Oktober 2019 oleh Bapak Drs. Wahono, S.T., M.Pd. selaku dosen Jurusan Teknik Mesin Universitas Negeri Malang. Terdapat dua validasi yang dilakukan oleh ahli materi, yaitu validasi konten atau isi modul dan validasi konstruk atau susunan modul. Variabel yang menjadi aspek pengamatan tentang modul cetak dapat disajikan pada tabel 1 dan tabel 2 berikut.

Tabel 1. Hasil Instrument Validasi Konstruk atau Susunan Modul

\begin{tabular}{|c|c|c|c|}
\hline No & Komponen yang Dinilai & Persentase (\%) & Klasifikasi \\
\hline 1 & Konsistensi sistematika sajian dalam kegiatan pembelajaran. & 75 & Cukup Valid \\
\hline 2 & Keruntutan penyajian. & 75 & Cukup Valid \\
\hline 3 & Soal latihan pada akhir kegiatan pembelajaran. & 100 & Valid \\
\hline 4 & Kunci jawaban soal latihan. & 100 & Valid \\
\hline 5 & Pengantar & 75 & Cukup Valid \\
\hline 6 & Daftar pustaka & 100 & Valid \\
\hline 7 & Rangkuman & 75 & Cukup Valid \\
\hline 8 & Bagian pendahuluan & 100 & Valid \\
\hline 9 & Bagian isi & 75 & Cukup Valid \\
\hline 10 & Bagian penutup & 75 & Cukup Valid \\
\hline \multicolumn{2}{|r|}{ Rata-rata } & 75 & Cukup Valid \\
\hline
\end{tabular}

Berdasarkan tabel 1 tentang tingkat kelayakan produk, didapatkan bahwa rata-rata persentase dari seluruh aspek yang diperoleh dari validasi konstruk oleh ahli materi yaitu 75\%, dinyatakan layak pada keterangan kriteria tingkat kelayakan produk namun perlu dilakukan revisi sesuai saran dari ahli materi.

Tabel 2. Hasil Instrument Validasi Konten Atau Isi Modul

\begin{tabular}{clcc}
\hline No & \multicolumn{1}{c}{ Komponen yang Dinilai } & Persentase (\%) & Klasifikasi \\
\hline 1 & Kelengkapan materi. & 100 & Valid \\
2 & Keluasan materi. & 100 & Valid \\
3 & Kedalaman materi & 75 & Cukup Valid \\
4 & Keakuratan konsep dan definisi. & 75 & Cukup Valid \\
5 & Keakuratan data dan fakta. & 75 & Cukup Valid \\
6 & Keakuratan contoh dan kasus. & 75 & Cukup Valid \\
7 & Keakuratan gambar, diagram, dan ilustrasi. & 75 & Cukup Valid \\
8 & Keakuratan istilah. & 50 & Kurang Valid \\
9 & Mendorong rasa ingin tahu. & 75 & Cukup Valid
\end{tabular}




\begin{tabular}{clcc}
10 & Menciptakan kemampuan bertanya & 75 & Cukup Valid \\
11 & Ketepatan struktur kalimat & 100 & Valid \\
12 & Keefektifan kalimat. & 75 & Cukup Valid \\
13 & Kebakuan istilah. & 75 & Cukup Valid \\
14 & Pemahaman terhadap pesan dan informasi. & 75 & Cukup Valid \\
15 & Kemampuan memotivasi peserta didik. & 75 & Cukup Valid \\
16 & Ketepatan tata bahasa. & 75 & Cukup Valid \\
17 & Ketepatan ejaan. & 100 & Valid \\
\hline & Rata-rata & 79,41 & Cukup Valid \\
\hline
\end{tabular}

Berdasarkan tabel 2 tentang tingkat kelayakan produk, didapatkan bahwa rata-rata persentase dari seluruh aspek yang diperoleh dari validasi konten atau isi oleh ahli materi yaitu $79,41 \%$, dinyatakan layak pada keterangan kriteria tingkat kelayakan produk namun perlu dilakukan revisi sesuai saran dari ahli materi.

\section{Hasil Face Validity oleh Kelompok Kecil}

Pada tahap uji coba modul cetak dilakukan kepada 10 mahasiswa angkatan 2019 D3 Teknik Mesin yang menempuh mata kuliah Ilmu Bahan Teknik. Variabel yang menjadi aspek pengamatan tentang kualitas media pembelajaran dapat disajikan pada tabel 3 berikut.

Tabel 3. Hasil Instrument Face Validity

\begin{tabular}{clcc}
\hline No & \multicolumn{1}{c}{ Komponen yang Dinilai } & Persentase (\%) & Klasifikasi \\
\hline 1 & Penggunaan Jenis font. & 92,5 & Valid \\
2 & Penggunaan ukuran font. & 90 & Valid \\
3 & Lay out/tata letak. & 80 & Valid \\
4 & Ilustrasi, grafis, gambar, foto. & 77,5 & Cukup Valid \\
5 & Desain tampilan. & 95 & Valid \\
6 & Spasi/ruang kosong. & 90 & Valid \\
7 & Format kertas.. & 90 & Valid \\
8 & Format halaman. & 77,5 & Cukup Valid \\
9 & Format kolom. & 77,5 & Cukup Valid \\
10 & Materi. & 100 & Valid \\
11 & Bab/sub bab & 85 & Valid \\
12 & Urutan dan susunan yang sistematis. & 87,5 & Valid \\
13 & Penempatan ilustrasi, grafis, gambar, foto. & $77,, 5$ & Cukup Valid \\
14 & Judul/sub judul & 82,5 & Valid \\
15 & Paragraf. & 80 & Cukup Valid \\
16 & Keterbacaan. & 90 & Cukup Valid \\
17 & Kejelasan informasi. & 85 & Valid \\
18 & Kesesuaian dengan kaidah Bahasa Indonesia. & 82,5 & Valid \\
19 & Penggunaan bahasa secara efektif dan efisien. & 77,5 & Cukup Valid \\
20 & Kejelasan tujuan. & 82,5 & Valid \\
21 & Kejelasan susunan kalimat. & 77,5 & Cukup Valid \\
22 & Kemudahan memahami kalimat & 85 & Valid \\
23 & Urutan penyajian & 85 & Valid \\
24 & Interaktif (stimulus dan respon) & 72,5 & Cukup Valid \\
25 & Kelengkapan informasi & 82,5 & Valid \\
\hline & & 84,1 & Valid \\
\hline
\end{tabular}

Berdasarkan tabel 3 tentang tingkat kelayakan produk, didapatkan bahwa rata-rata persentase dari seluruh aspek yang diperoleh dari face validity oleh kelompok kecil (10 mahasiswa) yaitu 84,1\%, dinyatakan sangat layak pada keterangan kriteria tingkat kelayakan produk.

\section{Hasil Validasi Ahli Media}

Validasi aplikasi modul oleh ahli media dilaksanakan pada tanggal 27 November 2019 oleh Bapak Marsono, S.Pd, M.Pd. Ph.D. selaku dosen Jurusan Teknik Mesin Universitas Negeri Malang. Variabel yang menjadi aspek pengamatan tentang kualitas media pembelajaran dapat disajikan pada tabel 4 berikut. 
Tabel 4. Hasil Validasi Ahli Media

\begin{tabular}{|c|c|c|c|}
\hline No & Komponen yang Dinilai & Persentase (\%) & Klasifikasi \\
\hline 1 & Pemilihan warna yang digunakan sudah sesuai. & 100 & Valid \\
\hline 2 & Judul dapat terbaca dengan jelas. & 100 & Valid \\
\hline 3 & Warna judul modul lebih menonjol daripada warna latar belakang. & 75 & Cukup Valid \\
\hline 4 & $\begin{array}{l}\text { Modul menggunakan dua jenis huruf agar lebih komunikatif dalam } \\
\text { menyampaikan informasi yang disampaikan. }\end{array}$ & 100 & Valid \\
\hline 5 & $\begin{array}{l}\text { Objek ditampilkan sesuai dengan bentuk, warna dan ukuran objeknya } \\
\text { sehingga tidak menimbulkan salah penafsiran maupun pengertian } \\
\text { peserta didik. }\end{array}$ & 75 & Cukup Valid \\
\hline 6 & $\begin{array}{l}\text { Penempatan unsur tata letak (judul, subjudul, kata pengantar, daftar isi, } \\
\text { ilustrasi,dll) konsisten berdasarkan pola. }\end{array}$ & 100 & Valid \\
\hline 7 & $\begin{array}{l}\text { Penempatan unsur tata letak pada setiap halaman mengikuti pola, tata } \\
\text { letak dan irama yang telah ditetapkan. }\end{array}$ & 100 & Valid \\
\hline 8 & $\begin{array}{l}\text { Susunan teks pada akhir paragraf terpisah dengan jelas, dapat berupa } \\
\text { jarak atupun dengan inden. }\end{array}$ & 100 & Valid \\
\hline 9 & Teks dengan ilustrasi ditampilkan dalam satu halaman. & 100 & Valid \\
\hline 10 & $\begin{array}{l}\text { Judul kegiatan ditulis secara lengkap disertai dengan angka kegiatan } \\
\text { belajar (kegiatan belajar 1, kegiatan belajar 2, dst) }\end{array}$ & 100 & Valid \\
\hline 11 & $\begin{array}{l}\text { Penulisan sub judul dan sub-sub judul disesuaikan dengan hirarki } \\
\text { penyajian materi ajar. }\end{array}$ & 75 & Cukup Valid \\
\hline 12 & $\begin{array}{l}\text { Ilustrasi dan keterangan gambar mampu memperjelas penyajian materi } \\
\text { baik dalam bentuk, ukuran yang proporsional serta warna yang menarik } \\
\text { sesuai objek aslinya. }\end{array}$ & 100 & Valid \\
\hline 13 & $\begin{array}{l}\text { Keterangan gambar ditempatkan berdekatan dengan ilustrasi dengan } \\
\text { ukuran lebih kecil daripada huruf teks. }\end{array}$ & 75 & Cukup Valid \\
\hline 14 & $\begin{array}{l}\text { Penempatan hiasan ilustrasi sebagai latar belakang tidak mengganggu } \\
\text { judul, teks, angka halaman. }\end{array}$ & 75 & Cukup Valid \\
\hline 15 & $\begin{array}{l}\text { Judul, sub judul, ilustrasi dan keterangan gambar ditempatkan sesuai } \\
\text { dengan pola yang telah ditetapkan sehingga tidak menimbulkan salah } \\
\text { interpretasi terhadap materi yang disampaikan. }\end{array}$ & 100 & Valid \\
\hline 16 & $\begin{array}{l}\text { Menggunakan dua jenis huruf sehingga tidak mengganggu dalam } \\
\text { menyerap informasi yang disampaikan. }\end{array}$ & 100 & Valid \\
\hline 17 & $\begin{array}{l}\text { Penggunaan variasi huruf digunakan untuk membedakan } \\
\text { jenjang/hirarki judul, sub judul serta memberikan tekanan pada } \\
\text { susunan teks. }\end{array}$ & 75 & Cukup Valid \\
\hline 18 & Spasi antar huruf normal & 100 & Valid \\
\hline 19 & Jenjang/hirarki judul-judul jelas, konsisten dan proporsional. & 100 & Valid \\
\hline 20 & $\begin{array}{l}\text { Aplikasi dapat digunakan dengan mudah saat pertama kali } \\
\text { menggunakannya. }\end{array}$ & 100 & Valid \\
\hline 21 & Aplikasi responsif pada saat pergantian materi. & 75 & Cukup Valid \\
\hline 22 & Aplikasi mudah diingat mahasiswa. & 75 & Cukup Valid \\
\hline 23 & Terdapat kesalahan pada sistem aplikasi. & 100 & Valid \\
\hline 24 & Mahasiswa nyaman dalam menggunakan aplikasi. & 75 & Cukup Valid \\
\hline \multicolumn{2}{|r|}{ Rata-rata } & 90,63 & Valid \\
\hline
\end{tabular}

Berdasarkan tabel 4 tentang tingkat kelayakan produk, didapatkan bahwa rata-rata persentase dari seluruh aspek yang diperoleh dari ahli media yaitu 90,63\%, dinyatakan sangat layak pada keterangan kriteria tingkat kelayakan produk namun perlu dilakukan revisi sesuai saran dari ahli media.

\section{Hasil Uji Coba Kelompok Besar (Daya Tarik)}

Pada tahap uji coba aplikasi modul dilakukan kepada 30 mahasiswa angkatan 2019 D3 Teknik Mesin yang menempuh mata kuliah Ilmu Bahan Teknik. Variabel yang menjadi aspek pengamatan tentang kualitas media pembelajaran dapat disajikan pada tabel 5 berikut. 
Tabel 5 Hasil Instrument Daya Tarik

\begin{tabular}{rlcc}
\hline No & \multicolumn{1}{c}{ Komponen yang Dinilai } & Persentase (\%) & Klasifikasi \\
\hline 1 & Saya senang belajar dengan modul ini & 80 & Sangat Setuju \\
2 & Modul yang saya gunakan tidak menarik & 29,17 & Kurang Setuju \\
3 & Materi yang disampaikan mudah dipahami & 78,33 & Sangat Setuju \\
4 & Ukuran dan bentuk huruf pada modul ini tidak & 46,67 & Kurang Setuju \\
& dapat dibaca dengan jelas & & \\
5 & Gambar pada modul ini menarik & 77,5 & Sangat Setuju \\
6 & Saya mudah memahami modul ini & 83,33 & Sangat Setuju \\
7 & Saya merasa terbantu belajar secara mandiri & 85 & Sangat Setuju \\
8 & Saya berminat memahami modul ini & 79,17 & Sangat Setuju \\
9 & Saya lebih sulit memahami materi jika & 44,17 & Kurang Setuju \\
& menggunakan modul ini & & Sangat Setuju \\
10 & Saya merasa tujuan pembelajaran lebih cepat & 83,33 & Sangat Setuju \\
& tercapai dengan menggunakan modul & & Sangat Setuju \\
& Saya senang belajar Ilmu Bahan Teknik & 85,83 & Sangat Setuju \\
\hline
\end{tabular}

Berdasarkan tabel 5 tentang kriteria skala Likert, didapatkan bahwa rata-rata persentase dari seluruh aspek yang diperoleh dari ujicoba daya tarik oleh kelompok besar (30 mahasiswa) yaitu 81,11\%, dinyatakan sangat menarik, sehingga modul cetak maupun modul berbasis aplikasi android dapat digunakan sebagai media pembelajaran secara mandiri.

Berdasarkan validasi konstruk dan konten oleh ahli materi, validasi keterbacaan oleh kelompok kecil, validasi media oleh ahli media, dan uji coba daya tarik oleh kelompok besar, maka didapatkan data sebesar 75\% untuk validasi konstruk dan $79,41 \%$ untuk validasi konten dari ahli materi, 70,59\% untuk validasi keterbacaan dari kelompok kecil, 90,63\% untuk validasi media dari ahli media, $81,11 \%$ untuk ujicoba daya tarik dari uji coba kelompok besar. Hasil rata-rata yang diperoleh disajikan pada Gambar 2 berikut.

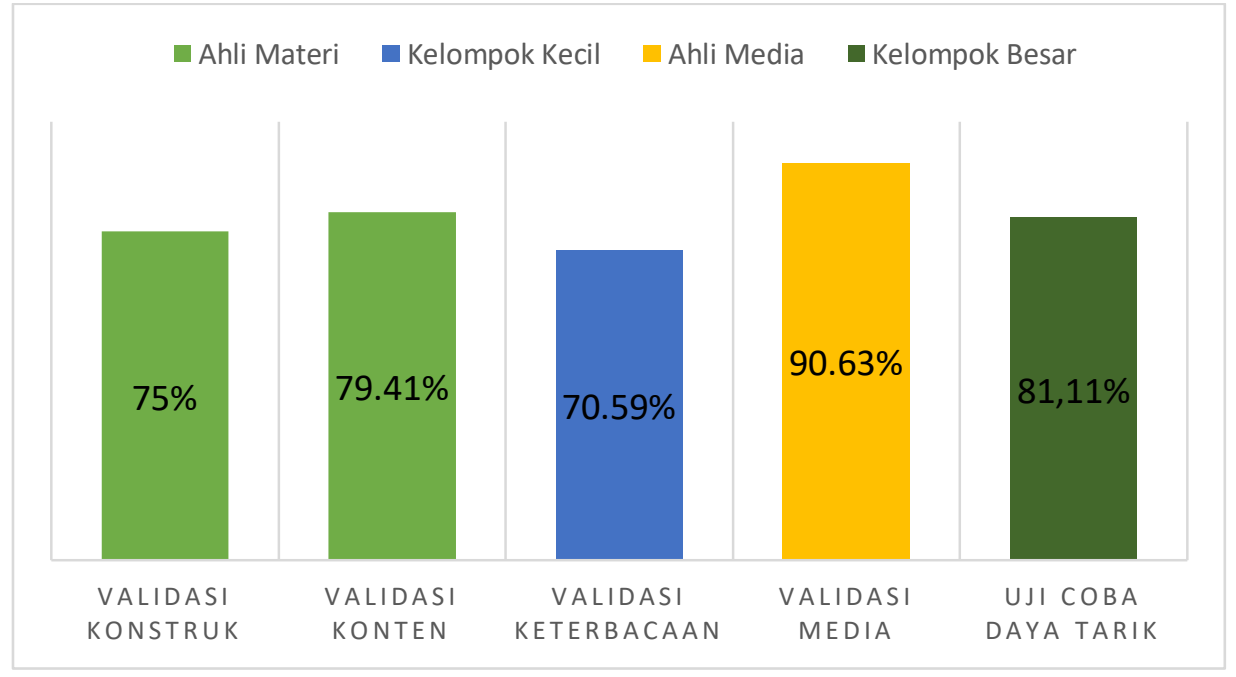

Gambar 2 Hasil Rata-Rata Validasi Dan Ujicoba

\section{Hasil Evaluasi}

Berdasarkan analisis data dan saran yang diberikan oleh ahli materi dan ahli media maka pengembang melakukan tindak lanjut dengan mengumpulkan data berupa saran-saran untuk dilakukan perbaikan. Berikut merupakan saran yang diberikan oleh ahli materi dan ahli media pada tabel 6 berikut. 
Tabel 6 Saran Dari Ahli Materi dan Ahli Media

\begin{tabular}{ccl}
\hline \multicolumn{2}{c}{ Saran Perbaikan } & \multicolumn{2}{c}{ Tindak Lanjut } \\
\hline $\begin{array}{c}\text { Saran dari Ahli Materi } \\
1\end{array}$ & $\begin{array}{l}\text { Merubah kompetensi atau tujuan } \\
\text { belajar. } \\
\text { Konsep yang harus dikenali }\end{array}$ & $\begin{array}{l}\text { Memperbarui kompetensi atau tujuan } \\
\text { belajar. } \\
\text { Penambahan materi pengerjaan panas } \\
\text { dan pengerjaan dingin. }\end{array}$ \\
Saran dari Ahli Media & $\begin{array}{l}\text { Penambahan sumber gambar atau tabel. } \\
3\end{array}$
\end{tabular}

Produk akhir dari pengembangan modul berbasis aplikasi android pada mata kuliah Ilmu Bahan Teknik dengan file ekstensi .apk yang bisa di install dan selanjutnya digunakan di semua smartphone android dengan sistem operasi Android Kitkat ke atas dan personal computer yang bisa menjalankan aplikasi android. Modul yang dikatakan sebagai produk jadi, sudah melewati tahap revisi. Revisi yang dilakukan pada modul mengacu pada saran ahli materi dan ahli media.

\section{Simpulan}

\section{PENUTUP DAN SARAN}

Modul berbasis aplikasi android pada mata kuliah Ilmu Bahan Teknik merupakan modul yang praktis untuk digunakan mahasiswa dalam belajar secara mandiri. Modul ini memadukan unsur-unsur pembentuk media yakni teks dan gambar. Tampilan dari produk aplikasi modul Ilmu Bahan Teknik yang sudah menjadi produk akhir pengembangan terdiri halaman cover, halaman menu utama, halaman panduan yang terdiri untuk mahasiswa, dosen dan penggunaan aplikasi, halaman kegiatan belajar yang terdiri bab-bab, halaman bab-bab yang terdiri dari materi, latihan soal, penilaian, kunci jawaban dan daftar rujukan, halaman informasi yang berisi data diri pengembang dan pembimbing modul Ilmu Bahan Teknik. Berdasarkan tujuan penelitian dan pengembangan modul berbasis aplikasi android untuk mata kuliah Ilmu Bahan Teknik program studi D3 TM UM, maka dapat ditarik kesimpulan sebagai berikut: 1) Modul yang telah dikembangkan menggunakan model pengembangan ADDIE (analysis, design, development, implementation, evaluation). 2) Modul yang dikembangkan telah dilakukan validasi konstruk oleh ahli materi. Berdasarkan hasil validasi didapatkan persentase sebesar $75 \%$ yang memiliki klasifikasi cukup valid dan dinyatakan layak dengan revisi. 3) Modul yang dikembangkan telah dilakukan validasi konten oleh ahli materi. Berdasarkan hasil validasi didapatkan persentase sebesar 79,41\% yang memiliki klasifikasi cukup valid dan dinyatakan layak dengan revisi. 4) Modul yang dikembangkan telah dilakukan validasi keterbacaan (face validity) kepada 10 mahasiswa yang sedang perkuliahan. Berdasarkan hasil validasi didapatkan persentase sebesar $84,1 \%$ yang memiliki klasifikasi valid dan layak digunakan. 5) Modul yang dikembangkan telah dilakukan validasi media oleh ahli media. Berdasarkan hasil validasi didapatkan persentase sebesar 90,63\% yang memiliki klasifikasi valid dan dinyatakan layak untuk digunakan. 6) Modul yang telah tervalidasi dan direvisi diuji cobakan kepada 30 mahasiswa D3 Teknik Mesin yang sedang menempuh mata kuliah Ilmu Bahan Teknik. Modul dinyatakan sangat menarik dilihat dari daya tarik keinginan mahasiswa untuk menggunakan modul berbasis aplikasi android. 7) Daya tarik modul dilihat dari hasil angket uji coba yang diisi mahasiswa. Modul dinyatakan sangat menarik, dilihat dari hasil angket uji coba didapatkan persentase sebesar $81,11 \%$ yang memiliki klasifikasi sangat setuju. Berdasarkan hasil tersebut, produk layak digunakan sebagai media penunjang proses belajar dan pembelajaran mandiri pada mata kuliah Ilmu Bahan Teknik untuk program studi D3 Teknik Mesin UM

\section{Saran}

Berikut ini adalah beberapa saran yang dapat digunakan untuk mengoptimalkan pemanfaatan media pembelajaran ini: 1) Materi yang terdapat pada modul ini bisa digunakan sebagai salah satu referensi dalam pembelajaran Ilmu Bahan Teknik atau Material Teknik. 2) Menggunakan perangkat smartphone android dengan sistem operasi minimal versi 4.4 (KitKat) ke atas agar modul dapat dioperasikan. 3) Sebelum menggunakan media pembelajaran ini pengguna diharapkan membaca dan memahami petunjuk penggunaan pada menu "Panduan" yang telah disediakan. 4) Pengguna diharapkan membaca buku-buku atau referensi belajar terkait yang lain supaya dapat menambah pengetahuan tentang materi yang dipelajari. 5) Pengembangan lebih lanjut terhadap produk selanjutnya diharapkan tidak hanya digunakan secara offline namun bisa dikembangkan dengan sistem online, sehingga pengembang bisa memperbarui fitur dan materi secara langsung dan pengguna bisa melakukan pembaruan terkait fitur dan materi tersebut. 6) Perlu ditambahkan materi-materi tentang diagram fasa yang lain supaya produk yang dihasilkan lebih komprehensif, karena produk ini hanya memuat materi material teknik, logam, polimer, dan komposit. 7) Penambahan video tentang proses pengolahan logam agar pengguna dapat lebih memahami teori pengolahan logam. Namun penambahan video tersebut harus mempertimbangkan kapasitas penyimpanan perangkat smartphone android agar ukuran aplikasi tidak terlalu besar. 


\section{DAFTAR RUJUKAN}

Arsyad, A. 2004. Media Pembelajaran. Penerbit PT Raja Grafindo Persada, Jakarta

Asmani, J. M. 2011. Tips Efektif Pemanfaatan Teknologi Informasi dan Komunikasi Dalam Dunia Pendidikan. Jogjakarta: Diva Press

Asnawir \& Usman, B. 2002 Media Pembelajaran, Jakarta: Ciputat Pres

Asyhar, R. 2012. Kreatif Mengembangkan Media Pembelajaran. Jakarta: Gaung Persada Press.

Daryanto. 2013. Menyusun Modul Bahan Ajar untuk Persiapan Guru dalam Mengajar. Yogyakarta: Gaya Media.

Degeng, I.N.S. 1989. Ilmu Pengajaran Taksonomi Variable, Jakarta: Departemen Pendidikan dan Kebudayaan

Direktorat Pembinaan Sekolah Menengah Atas. (2008). Panduan pengembangan bahan ajar. Jakarta: Departemen Pendidikan Nasional.

Djaali \& Muljono, P. 2008. Pengukuran Dalam Bidang Pendidikan. Jakarta: Grasindo.

Mulyatiningsih, E. 2011. Riset Terapan: Bidang Pendidikan dan Teknik. Yogyakarta: UNY Press.

Pedoman Penulisan Karya Ilmiah Edisi 2017. Universitas Negeri Malang.

Peraturan Menteri Pendidikan Nasional Nomor 41 Tahun 2007 mengenai Standar Proses untuk Satuan Pendidikan Dasar dan Menengah.

Sagala, S. 2006.Konsep dan Makna Pembelajaran. Bandung: Alfabeta.

Sarwono, J. 2006. Metode Penelitian Kuantitatif Dan Kualitatif. Yogyakarta: Graha Ilmu.

Semiawan, C. 2010. Metode Penelitian Kualitatif. Jakarta: PT Gramedia Widiasarana Indonesia.

Siyoto, S. 2015. Dasar Metodologi Penelitian. Yogyakarta: Literasi Media Publishing.

Subkhan, E. 2016. Sejarah dan Paradigma Teknologi Pendidikan Untuk Perubahan Sosial. Jakarta: Prenadamedia Group

Sudjana, N. 2014. Penilaian Hasil Proses Belajar Mengajar. Bandung: PT. Remaja Rosdakarya

Sugiyono. 2011. Metode Penelitian Kuantitatif, Kualitatif, dan R\&D. Bandung: Alfabeta.

Sukiman. 2012. Pengembangan media pembelajaran. Yogyakarta: Pedagogia.

Sukmadinata, N. S. 2007. Metode Penelitian Pendidikan. Bandung: Remaja Rosdakarya.

Suparman, A. 1997. Desain Intruksional. Jakarta: PAU-PPAI Direktorat Jendral Pendidikan Tinggi Departemen Pendidikan Dan Kebudayaan.

Wirawan, P.W. 2011. Pengembangan Kemampuan E-Learning Berbasis Web ke dalam M-Learning. Jurnal Universitas Diponegoro. (Vol. 2. No. 4 Hlm 22-23).

Zain, A \& Djamarah, S.B. 2006. Strategi Belajar Mengajar. Jakarta: Rineka Cipta 